朝食摂取 3 時間後における運動前の糖質摂取量の相違が運動誘発性低血糖に及ぼす影響 八田 早那子 ${ }^{1,2}$, 藤江 衣織 ${ }^{1}$, 東郷 将成 ${ }^{3}$, 柴田 啓介 ${ }^{1,4}$, 木村 宣哉 ${ }^{4}$, 瀧澤 一騎 ${ }^{5}$, 神林 勲 $^{6}$, 山口 太- ${ }^{1,4^{*}}$

\title{
Effects of pre-exercise ingestion of different amounts of carbohydrate at three hours after feeding breakfast on exercise-induced hypoglycemia
}

\author{
Sanako Hatta ${ }^{1,2}$, Iori Fujie ${ }^{1}$, Masanari Togo ${ }^{3}$, Keisuke Shibata ${ }^{1,4}$, Nobuya Kimura ${ }^{4}$, \\ Kazuki Takizawa ${ }^{5}$, Isao Kambayashi ${ }^{6}$ and Taichi Yamaguchi ${ }^{1,4^{*}}$ \\ ${ }^{1}$ 酪農学園大学大学院酪農学研究科食品栄養科学専攻, T069-8501 北海道江別市文京台緑町582 (Food and Nutrition Sci- \\ ence, Graduate School of Dairy Sciences, Rakuno Gakuen University, 582 Bunkyodai-Midorimachi, Ebetsu, Hokkaido \\ 069-8501, Japan) \\ ${ }^{2}$ 医療法人社団網走中央病院， ⿳亠丷厂093-0006 北海道網走市南6 条東1丁目 7 (Abashiri Central Hospital, 7 Minami-6 Higashi-1, \\ Abashiri, Hokkaido 093-0006, Japan) \\ 3 旭川大学短期大学部生活学科食物栄養専攻， =079-8501 北海道旭川市永山3条23丁目1-9 (Food and Nutrition Major, \\ Department of Life Sciences, Asahikawa University Junior College, 3-23-1-9 Nagayama, Asahikawa, Hokkaido 079-8501, \\ Japan) \\ ${ }^{4}$ 酪農学園大学農食環境学群食と健康学類, $=069-8501$ 北海道江別市文京台緑町 582 (Department of Food Science and \\ Human Wellness, College of Agriculture, Food and Environment Sciences, Rakuno Gakuen University, 582 Bunkyodai- \\ Midorimachi, Ebetsu, Hokkaido 069-8501, Japan) \\ 5 一般社団法人身体開発研究機構, $=$ \% 060-0061 北海道札幌市中央区南1条西5丁目 (Institute of Physical Development Re- \\ search, Minami-1, Nishi-5, Chuo-ku, Sapporo, Hokkaido 060-0061, Japan) \\ ${ }^{6}$ 北海道教育大学札幌校, =002-8501 北海道札棍市北区あいの里5条3丁目 1-3 (Department of Education, Hokkaido Uni- \\ versity of Education Sapporo, 1-3 Ainosato 5-3, Kita-ku, Sapporo, Hokkaido 002-8501, Japan)
}

Received: March 2, 2021 / Accepted: April 26, 2021

\begin{abstract}
The purpose of this study was to compare effects of different amounts of carbohydrate (CHO) in beverage on plasma glucose (GLU) concentration during exercise after feeding breakfast. Seven healthy Japanese male subjects performed 30-min cycling at an intensity on the $75 \%$ of maximal load at 3-h after feeding breakfast under 3 types of $\mathrm{CHO}(0 \mathrm{~g}, 30 \mathrm{~g}$ and $150 \mathrm{~g}$ ) beverage conditions. The subjects ingested $500 \mathrm{~mL}$ of beverage dissolved each amount of glucose at 30-min before the exercise. The GLU concentrations were measured at 35- and 10-min before the exercise and every 5-min during the exercise. The minimum GLU concentrations under the $30 \mathrm{~g}$ condition for all subjects were lower than a criterion for hypoglycemic (72 $\mathrm{mg} / \mathrm{dL}$ ). The mean value also fell below the criterion at from 10- to 20-min during exercise. The minimum GLU concentration under the $150 \mathrm{~g}$ condition of only one subject was lower than the criterion, but the mean value did not fall below the criterion. Significant negative correlations were found between the subjects' maximum oxygen uptake $\left(\mathrm{V}_{2} \max \right)$ and the decreases in GLU concentration from maximum to minimum under both the $30 \mathrm{~g}(\mathrm{r}=-0.947, \mathrm{p}<$ $0.01)$ and $150 \mathrm{~g}$ conditions $(\mathrm{r}=-0.884, \mathrm{p}<0.01)$. This study clarified that feeding breakfast at 3-h before the exercise followed by the $30 \mathrm{~g}$ CHO beverage ingestion at $30 \mathrm{~min}$ before the exercise induced exercise-induced hypoglycemia, and that the subjects with higher $\dot{\mathrm{V}}_{2}$ max had the greater decreases in GLU concentration.
\end{abstract}

Jpn J Phys Fitness Sports Med, 70(4): 247-256 (2021)

Keywords : hypoglycemic, plasma glucose, cycling, sports nutrition, maximal oxygen uptake

*Correspondence: taichi@rakuno.ac.jp 


\section{緒言}

持久的な運動の主要なエネルギー源は糖質ならびに脂 質である ${ }^{1)}$ 。このうち, 糖質の体内貯蔵量は脂質のそれ に比べて少ない，そのため，運動前日ならびに運動当日 には糖質を積極的に摄取しなければならない，持久的な 運動前の糖質摂取方法については, 運動の強度や時間に よって目安量が示されている。例えば，90分未満の持久 的な運動に向けては, 前日までの 24 時間に体重 $1 \mathrm{~kg}$ あ たり $7 \sim 12 \mathrm{~g}$, 当日は運動 $1 \sim 4$ 時間前に体重 $1 \mathrm{~kg}$ あ たり 1〜 $4 \mathrm{~g}$ の糖質を摂取することが推奨されている ${ }^{2)}$. また，運動当日の糖質摂取に関しては，摂取タイミング についても注意喚起がなされており，運動開始 30〜45分 前の糖質摂取は控えるようにとされている。 なぜなら， 運動 30 45分前に糖質を摂取して運動を開始すると, 運

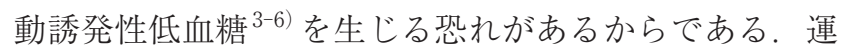
動誘発性低血糖が生じると, 脂肪分解の抑制や糖質利用 の交進を引き起こし, 持久的な運動パフォーマンスを低 下させる可能性がある7 ${ }^{7}$.

これまで運動前の糖質摂取が運動誘発性低血糖に及 ぼす影響を検討した研究の多く ${ }^{3-6)}$ は欧米人を対象とし ており，欧米人と比ベてインスリン分泌能が低い日本 人) でも運動誘発性低血糖が生じるか否かは不明であっ た，この先行研究における課題を解決するべく, 先頃, Kondo $\check{~}^{9)}$ は日本人を対象に, 絶食条件に加え, 朝食を 摂取した条件のもと運動開始 30 分前に $150 \mathrm{~g}$ のブドウ糖 を含む飲料を摂取させ，運動誘発性低血糖の発生の有無 を検討した。 その結果, 血糖值の平均值では, 両条件と もに運動誘発性低血糖は生じなかった。一方で, 被験 者個人の血糖值の変動を観察すると, 両条件ともに運 動誘発性低血糖を生じた被験者が抒り, 絶食条件では インスリン初期分泌能が高い者で, また, Kondoらは関 連の別の報告 ${ }^{10)}$ において, 朝食摂取条件では最大酸素 摂取量 (maximum oxygen uptake: $\dot{\mathrm{V}} \mathrm{O}_{2} \max$ ) が高い者 で, 運動誘発性低血糖が生じたことを確認した。ささらに, Koma and Terasawa ${ }^{11)}$ は日本人を対象に, 朝食摂取後, 運動開始前 30 分前に被験者の体重 $1 \mathrm{~kg}$ 当たり $1.5 \mathrm{~g}$ （被 験者の平均体重が $62.7 \pm 4.9 \mathrm{~kg}$ であったことから $94.1 \pm$ $7.4 \mathrm{~g}$ ) のブドウ糖を含む飲料を摂取させ, 運動誘発性低 血糖の発生の有無を確認したところ, 同様に血糖值の平 均值では運動誘発性低血糖は生じなかったことを報告し ている.

このようにKondo $~^{9)}$, 近藤ら ${ }^{10)}$ およびKoma and Terasawa $^{11)}$ の報告は日本人を対象に朝食摂取条件下に おいて検討を行い, 多くの示唆を示した点で意義深い研 究であったものの, 運動開始前に摂取された $150 \mathrm{~g}$ ある いは94.1 g という糖質量は運動直前の摂取量としては過 多であったように思える。例えば，運動時に頻繁に摂取
されるスポーツドリンクに含まれる糖質量は, $500 \mathrm{~mL}$ のペットボトル飲料 1 本で $20 \sim 30 \mathrm{~g}$ 程度である。 500 $\mathrm{mL}$ のスポーッドリンクのペットボトル飲料は, 熱中 症予防の観点から運動前に必要とされている250～500 $\mathrm{mL}^{12)}$ の水分摂取量を満たし，かつ， $1 \sim 2$ 時間の中高 強度の持久的な運動前や運動中に摂取すべき糖質量であ る 1 時間当たり $30 \mathrm{~g}^{13)}$ を摂取できることから運動直前 に飲用されている。 よって, 日本人を対象に, 朝食摂取 後, 運動開始前に500 $\mathrm{mL}$ のペットボトル飲料 1 本のス ポーツドリンクと同等量の糖質を摂取した場合に運動誘 発性低血糖が発生するのか否かについて検討を行うこと は，本邦に扔ける運動誘発性低血糖に関する重要な研究 課題であると考える.

そこで本研究では, 日本人を対象に運動開始 3 時間前 に朝食を摂取した後, 運動開始30分前にスポーツドリン クと同等量の $30 \mathrm{~g}$ のブドウ糖を含む飲料を摂取するこ とが運動中の血糖值に及ぼす影響を，150 gのブドウ糖 を含む飲料摂取条件掞よびブドウ糖を含まない $(0 \mathrm{~g})$ 飲料摂取条件と比較することを目的とした。なお，Jentiens ら $^{3)}$ は欧米人を対象とした絶食下の運動誘発性低 血糖に関する研究に抢いて, 運動開始 45 分前の $0 \mathrm{~g}, 25$ $\mathrm{g}, 75 \mathrm{~g}$ 打よび200 g の糖質摂取によって運動中の血糖值 の変動には相違がなかったことを報告している。また, 前述の通り, 日本人を対象に朝食摂取後の運動開始前の 糖質飲料摂取が運動中の血糖值の変動に及ぼす影響を検 討したKondoらの研究 ${ }^{9)}$ では, 糖質量 $150 \mathrm{~g}$ に扔いて, Koma and Terasawaの研究 ${ }^{11)}$ では, 糖質量 $94.1 \mathrm{~g}$ にお いて, 全被験者の血糖值の平均值でみると, 運動誘発性 低血糖は発生しなかった。 よって, 本研究においても, 朝食摂取後の運動開始前の $150 \mathrm{~g}$ の糖質飲料摂取条件だ けでなく, $30 \mathrm{~g}$ の糖質飲料摂取条件においても運動中の 血糖値の平均值では運動誘発性低血糖は観察されないと の仮説のもと検討を行った.

\section{方法}

被験者 被験者は本学の課外活動団体で競技種目（バス ケットボール 2 名, 硬式野球 2 名, 自転車ロード 1 名, バ ドミントン 1 名, 抢よびバレーボール 1 名）を日常的に 行ない，かつ本学のトレーニングセンターに定期的に通 い, 有酸素性トレーニング抒よびレジスタンストレーニ ングの両方を行なっている健康な日本人男子大学生 7 名 [年齢： $20.4 \pm 1.0$ 歳, 身長 : $171.9 \pm 4.3 \mathrm{~cm}$, 体重 : $69.3 \pm$ $5.3 \mathrm{~kg}$, 体脂肪率 : $11.6 \pm 2.8 \%$, 筋肉量 : $58.0 \pm 3.6 \mathrm{~kg}$, 体重当たりの $\dot{\mathrm{VO}_{2}} \max : 50.5 \pm 7.5 \mathrm{~mL} / \mathrm{kg} /$ 分, 最大運動 負荷（Wmax）：261.4 $\pm 48.0 \mathrm{~W}$ ，体重当たりの Wmax：3.8 $\pm 0.7 \mathrm{~W} / \mathrm{kg}]$ であった，被験者のサンプルサイズは，主 要な測定項目である血糖值の測定值（3 条件 $\times 8$ 時点） を鑑み, 水本㧍よび竹内の指摘 ${ }^{14)}$ に従い, 統計ソフト 
G*Power 3.1 (Allgemeine Psychologie und Arbeitspsychologie, Heinrich-Heine-Universität Düsseldorf) を用 いて, 最少人数 7 名と算出し, 決定した。全ての被験者 に対し事前に実験の目的, 内容捛よび危険性について十 分に説明を行い，書面にて実験参加の同意を得た，実験 実施前のスクリーニングとして, 喫煙, 糖尿病の罹患, 服薬の有無を確認したが, 該当する被験者はいなかった。 なお, 本研究は酪農学園大学に打ける人を対象とする医 学系研究倫理審査委員会により承認（15-9）を得て実施 した.

実験の概要 全ての被験者は，事前に身長，体重，体組 成の測定および自転車運動を用いた多段階漸増負荷試験 を行い， $\dot{\mathrm{V}} \mathrm{O}_{2} \max$ 抒よびWmaxの決定を行った，本実験 では，被験者は，運動実施前日の 22 時までに指定した 夕食 (エネルギー : $921 \mathrm{kcal}$, たんぱく質 : $20.0 \mathrm{~g}$, 脂質 : $17.1 \mathrm{~g}$, 炭水化物：171.2 g) を摄取し, 運動当日の運動 開始 3 時間前までに，指定した朝食（エネルギー：760 $\mathrm{kcal}$, たんぱく質: $24.6 \mathrm{~g}$, 脂質: $24.9 \mathrm{~g}$, 炭水化物 : $109.1 \mathrm{~g}$ )

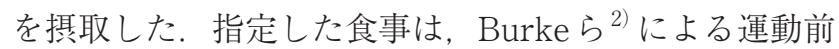
の糖質摂取目安量を満たす食事とし, 夕食は 24 時間で体 重 $1 \mathrm{~kg}$ あたり 7 〜 $12 \mathrm{~g}$ の糖質量を 3 食分で除した糖質 量（体重 $1 \mathrm{~kg}$ あたり $2.3 \sim 4 \mathrm{~g}$ ), 朝食は体重 $1 \mathrm{~kg}$ あたり 1〜 $4 \mathrm{~g}$ の糖質量を満たす食事とした。

実験当日は（Fig. 1), 実験室来室後, 30分程度安静を 保持したのち, 安静時（-35分）の採血を行った，採血 終了後, 糖質飲料を 2 分以内に摂取した。飲料摂取条件 として, 同一の飲料水 $500 \mathrm{~mL}$ にブドウ糖を溶解しない $0 \mathrm{~g}$ 条件, $30 \mathrm{~g}$ および $150 \mathrm{~g}$ のブドウ糖を溶解した $30 \mathrm{~g}$ 条件, $150 \mathrm{~g}$ 条件の 3 条件を設定した。各被験者の 3 条 件の実験は別日に実施し, 実施順序はランダマイズし た. 糖質飲料摂取後, 20 分間の座位安静状態を保持した。 20 分の安静後 (-10分) に採血を行い, 採血終了後, 自 転車エルゴメーターに乗り, ウォーミングアップを行っ
た. 5 分間のウォーミングアップ後, $75 \% \mathrm{Wmax}$ 強度で 30 分間の自転車こぎ運動を行った，運動中は運動開始 5 分より 5 分ごとに指先から血糖值の測定を行った．さら に, 運動開始15分, 30 分後は血糖值の測定に加え, 时正 中皮静脈から採血を行った。 また，脱水を予防するため に決められた時点で水分摂取を行った。

なお，全ての被験者は各条件の実験を 1 週間以上の期 間を扮き，被験者のサーカディアンリズムを考慮し，同 時間帯に実施した。また，被験者には，実験期間中，標 準的な食事，運動および睡眠を促し，実験実施24時間前 からは激しい運動や飲酒，カフェイン摂取の禁止を促し た。すべての実験は，室温 $24^{\circ} \mathrm{C}$ ，相対湿度 $50 \%$ に設定し た実験室内で実施した。

事前測定 被験者は, 身長を測定し, インピーダンス式 体重体組成計（BC-622, 株式会社夕ニ夕）を用いて体重 抢よび体組成の測定を行った。その後，心拍計のトラ ンスミッター (HIトランスミッター, Polar Electro Oy) および呼気ガス分析装置 $(\mathrm{AE}-300 \mathrm{~S}$, ミナト医科学株式 会社）のマスクを装着した。自転車エルゴメーター上 で 3 分間の安静状態を保持したのちに $30 \mathrm{~W}$ で 3 分間の ウォーミングアップを実施した。その後, 回転数を 60

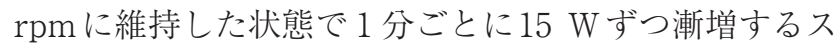
テップ負荷にて疲労困僙まで追い込んだ，疲労困僙の判 断基準 ${ }^{15)}$ は, 1 . 回転数が50 rpmを下回った時点, 2 . 最大心拍数が（220-年齢）を超えた時点， 3 ．被験者 が運動継続困難と判断した時点とした。呼気ガス採取法 にて 10 秒毎に得られた酸素摂取量の最大值を $\dot{\mathrm{V}} \mathrm{O}_{2} \max$, さらにその時の負荷量をWmax とした，各ステップにお ける負荷と $\dot{\mathrm{V}}_{2}$ の関係から, 運動で用いるWmax の相対 值，30\%，40\%，50\%，60\%，70\%および $75 \%$ に相当す る強度を算出した。

試験飲料 試験飲料はブドウ糖を含まない $0 \mathrm{~g}$ の飲料水

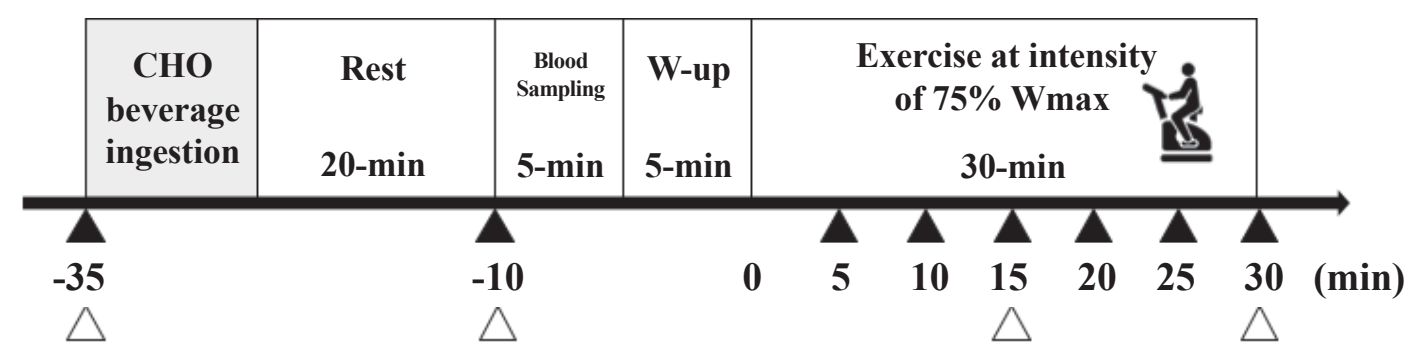

A : Measurement of plasma glucose concentration

\section{$\triangle$ : Water ingestion \\ Measurement of serum insulin concentration}

Fig. 1 Exercise protocol and timing of measurements. 
（森の水だより 日本アルプス, 日本コカ・コーラ株式会 社）と $30 \mathrm{~g}, 150 \mathrm{~g}$ のブドウ糖（扶桑薬品工業株式会社） を $500 \mathrm{~mL}$ の飲料水に溶解したものとした。 よって, $30 \mathrm{~g}$ および $150 \mathrm{~g}$ 条件に打ける糖質飲料の糖質の濃度はそれ ぞれ $6 \%$ および $30 \%$ であった. 飲料の摂取時間は，2 分 以内とし, 飲料の提供前の温度は $0 \mathrm{~g}$ 条件で $16.5 \pm 0.7^{\circ} \mathrm{C}$, $30 \mathrm{~g}$ 条件で $16.6 \pm 0.5^{\circ} \mathrm{C}, 150 \mathrm{~g}$ 条件で $16.2 \pm 0.9^{\circ} \mathrm{C}$ であった。

自転車漕ぎ運動 被験者は自転車エルゴメーターを用い て，5分間のウォーミングアップを行った．回転数は60 $\mathrm{rpm}$ に維持し， $30 \% \mathrm{Wmax}$ 強度から 1 分ごとに，40\%, 50\%，60\%，70\%Wmax強度の負荷に漸増させた。 5 分 間のウォーミングアップ終了直後に $75 \% \mathrm{Wmax}$ 強度の負 荷に設定し, 回転数を $60 \mathrm{rpm}$ に維持したまま 30 分間の 運動を実施した. $75 \% \mathrm{Wmax}$ 強度に抢ける30分間の運動 は, $40 \%$ 抢よび $55 \% \mathrm{Wmax}$ 強度に打ける同時間の運動よ りも筋グリコーゲンならびに血糖をエネルギー源として 利用するとされている ${ }^{16)}$. また，本研究に扔ける $30 \mathrm{~g} の$ 糖質飲料条件は, 本来 $1 \sim 2$ 時間継続される運動を想定 し ${ }^{13)}$ ，糖質必要量を設定した条件であるが，運動開始初 期の血糖值変動を確認することが目的であったため, 実 験に抢ける運動時間は30分間とした，なお，脱水による 影響を除外するため, 熱中症予防ガイドブック ${ }^{12)}$ に基づ き, 各条件で-35分, -10 分, 15 分, 30 分時の肘正中皮静 脈採血前に $250 \mathrm{~mL}$ の水分摂取を行った.

血液生化学分析 血液生化学分析は, 糖質代謝関連項目 として, 血糖值掞よびインスリン濃度を測定した。血糖 值はグルテストNeoスーパー（GT-1820, 株式会社三和 化学研究所）を用いて験者が指先血より測定した．イン スリン濃度は保健師あるいは看護師が肘正中皮静脈より 採血を行い, 分析については外注依頼（札幌臨床検査セ ンター株式会社）した。

統計解析 本研究の結果は, 平均值士標準偏差 (Mean $\pm \mathrm{SD}$ ）で示した，各指標の推移の摂取条件間の比較は, 重複測定の二元配置分散分析（摂取条件 $\times$ 測定時間）を 用い，交互作用の有無を確認した，交互作用が認められ た場合および各指標の測定值の摂取条件間の比較には, 等分散および正規性の認められたデー夕については, 繰 り返しのある一元配置分散分析後に Tukey-Kramer 法 を用いて多重比較検定を行った。また，等分散あるいは 正規性の認められないデー夕については, Friedman 検 定後に, Scheffe法を用いて多重比較検定を行った。各 指標間の相関関倸はPearsonの相関分析を用いて検討し た。また， $0 \mathrm{~g}$ 条件において，低血糖の基準值 $(72 \mathrm{mg} /$ $\mathrm{dL}$ ）を下回った群を低血糖群, 基準値を下回らなかっ た群を正常血糖群とし，2 群間の血糖值の差の検定には
Student の $\mathrm{t}$ 検定, $\dot{\mathrm{V}} \mathrm{O}_{2} \max$ およびインスリン濃度の差 の検定にはWelchの t 検定を用いた，すべての統計解析 は, 統計ソフトエクセル統計Statcel3 (オーエムエス出版) を使用し、いずれも危険率 $5 \%$ 未満を有意水準とした。

\section{結果}

血糖值およびインスリン濃度 血糖值の平均值の経時変 化をFig. 2 に, $0 \mathrm{~g}$ 条件, $30 \mathrm{~g}$ 条件, $150 \mathrm{~g}$ 条件における 各被験者の最大血糖值から最低血糖値までの推移を Fig. 3-A, B, Cに示した. 血糖值は $30 \mathrm{~g}$ 条件, $150 \mathrm{~g}$ 条件で-10 分時に最高值に到達し, 運動開始後低下した. $30 \mathrm{~g}$ 条件 では，10〜20分時に扔いて平均值が低血糖の基準值（72 $\mathrm{mg} / \mathrm{dL}$ ) を下回った（Fig. 2). また, 血糖值の最低值 が出現する時間には個人差が認められたものの, すべて の被験者が低血糖の基準值を下回った (Fig. 3-B).一方, $150 \mathrm{~g}$ 条件では 1 名の被験者のみ 10 分時において基準值 を下回ったが (Fig. 3-C), 平均值では低血糖の基準值を 下回らなかった（Fig. 2)。 $0 \mathrm{~g}$ 条件の平均值は, -35 分 時よりほぼ同水準で推移し, 低血糖の基準值は下回らな かったものの，3名の被験者で基準值を下回った（Fig. 3-A）。血糖值の時間と条件に有意な交互作用が認めら れ $(\mathrm{F}=7.783, \mathrm{p}<0.01)$, 多重比較検定の結果, -10 分時に おいて, $30 \mathrm{~g}$ 条件および $150 \mathrm{~g}$ 条件が $0 \mathrm{~g}$ 条件よりも有 意に $(\mathrm{p}<0.01)$ 高値を示した。 また, 20〜30分時の間で

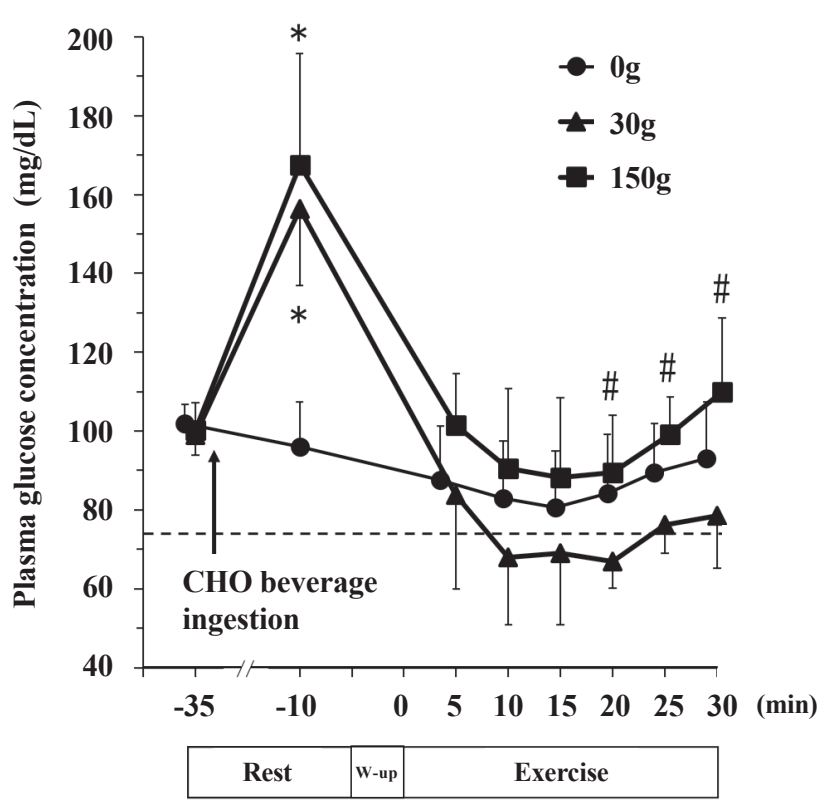

Fig. 2 Time courses of plasma glucose concentration. The dashed line was showing hypoglycemia level (plasma glucose of $\leqq 72 \mathrm{mg} / \mathrm{dL}$ )

${ }^{*} \mathrm{p}<0.01$ : Significantly different between $0 \mathrm{~g}$ and $30 \mathrm{~g}$ or $150 \mathrm{~g}$ of carbohydrate beverage conditions.

\#: $\mathrm{p}<0.05$ : Significantly different between $30 \mathrm{~g}$ and $150 \mathrm{~g}$ of carbohydrate beverage conditions. 
$150 \mathrm{~g}$ 条件が $30 \mathrm{~g}$ 条件よりも有意に（p<0.05）高值を示 した。なお，低血糖の基準值を下回る被験者が観察され たものの，運動中に体調不良を訴えるものはいなかった．

インスリン濃度の平均值の経時変化をFig. 4 に示した。 インスリン濃度も血糖值と同様に, $30 \mathrm{~g}$ 条件, $150 \mathrm{~g}$ 条 件で-10分時に最高值に到達し，15分時に低下した。イ
ンスリン濃度の経時変化は条件間で有意な交互作用が認 められ $(\mathrm{F}=9.77, \mathrm{p}<0.01), 30 \mathrm{~g}$ 条件が $0 \mathrm{~g}$ 条件と比較し て-10分時において有意に $(\mathrm{p}<0.01)$ 高值であった。さ らに, $150 \mathrm{~g}$ 条件は $0 \mathrm{~g}$ 条件と比較して -10 分時 $(\mathrm{p}<0.01)$, 15 分時 $(\mathrm{p}<0.05)$ において有意に高值を示した。また, $150 \mathrm{~g}$ 条件では30分時において $30 \mathrm{~g}$ 条件と比較して有意
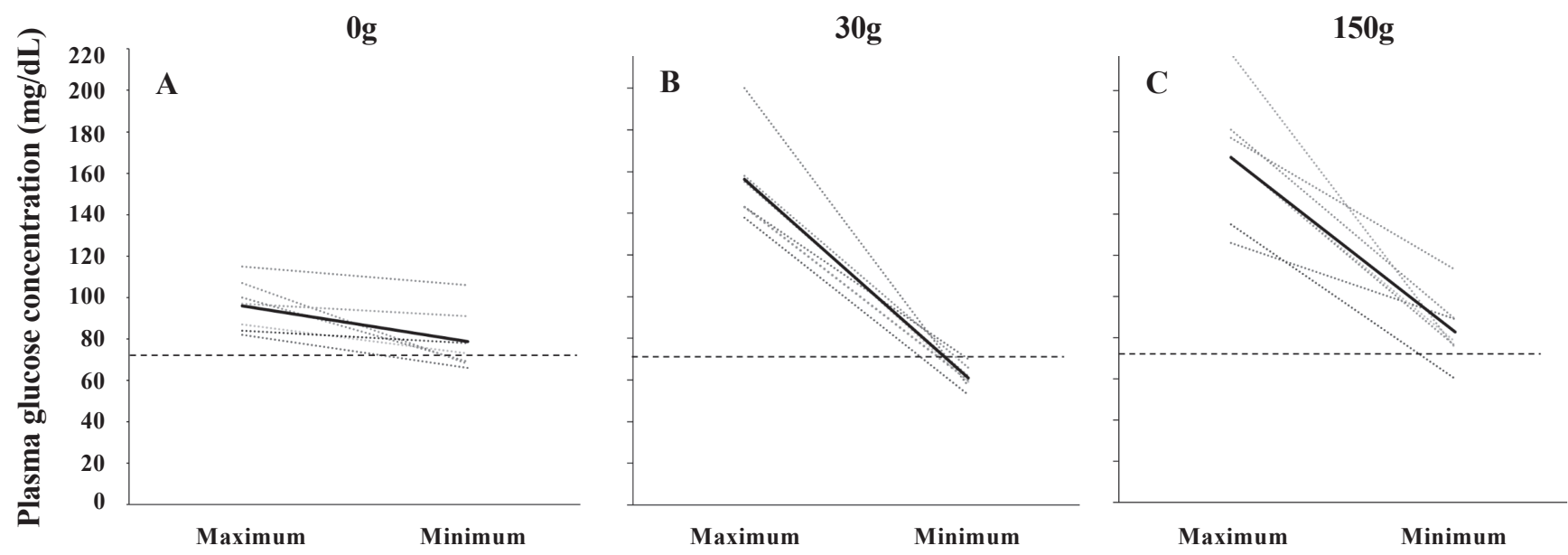

Fig. 3 Changes in mean values and individual subject's plasma glucose from maximum to minimum in $0 \mathrm{~g}$ (A), 30g (B) and $150 \mathrm{~g}$ (C) of carbohydrate beverage conditions. The bold lines were showing changes in mean values. The dotted lines were showing individual subject's changes. The dushed lines were showing hypoglycemia level (plasma glucose of $\leqq 72 \mathrm{mg} / \mathrm{dL}$ ).

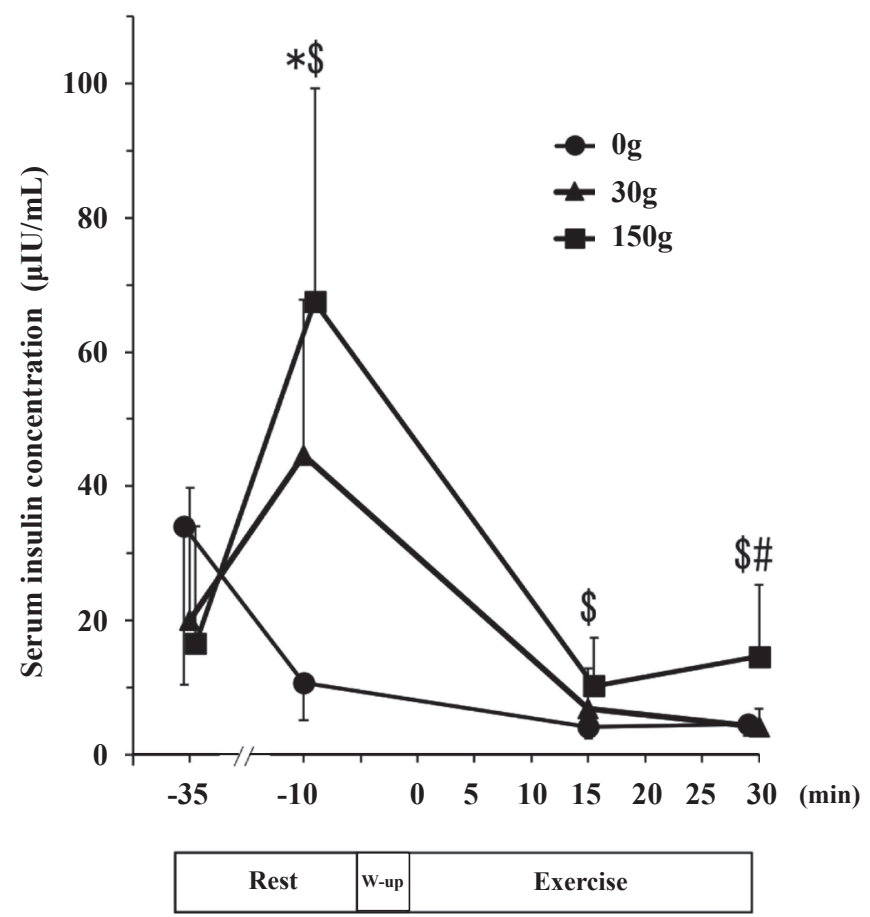

Fig. 4 Time courses of serum insulin concentration.

$*: \mathrm{p}<0.01$ : Significantly different between $0 \mathrm{~g}$ and $30 \mathrm{~g}$ of carbohydrate beverage conditions.

$\$: \mathrm{p}<0.05$ : Significantly different between $0 \mathrm{~g}$ and $150 \mathrm{~g}$ of carbohydrate beverage conditions.

$\#: \mathrm{p}<0.05$ : Significantly different between $30 \mathrm{~g}$ and $150 \mathrm{~g}$ of carbohydrate beverage conditions. 
に（p<0.05）高值を示した.

$30 \mathrm{~g}$ 条件および150 g条件におけるインスリン最大濃度 と血糖值減少量との関係 $30 \mathrm{~g}$ 条件, $150 \mathrm{~g}$ 条件に打け る-10分時のインスリン最大濃度と血糖值の最大值から 最小值への減少量との関係を Fig. 5-A, Bに示した. $30 \mathrm{~g}$ 条件, $150 \mathrm{~g}$ 条件ともにインスリン最大濃度と血糖值減 少量との間に有意な相関関係 $(30 \mathrm{~g}$ 条件 : $\mathrm{r}=0.163,150$ $\mathrm{g}$ 条件 : $\mathrm{r}=0.210$ ）は認められなかった.
体重当たりの $\mathrm{VO}_{2} \max$ おび $\mathrm{Wmax}$ と $30 \mathrm{~g}$ 条件および $150 \mathrm{~g}$ 条件における血糖值減少量との関係 体重当たり の $\mathrm{V}_{2} \max$ と $30 \mathrm{~g}$ 条件, $150 \mathrm{~g}$ 条件に扔ける血糖值減少 量との関係を Fig. 6-A, B に示した. $30 \mathrm{~g}$ 条件, $150 \mathrm{~g}$ 条 件ともに体重当たりの $\dot{\mathrm{V}} \mathrm{O}_{2} \max$ と血糖值減少量との間に 有意な負の相関関係 $(30 \mathrm{~g}$ 条件 : $\mathrm{r}=-0.947, \mathrm{p}<0.01,150$ $\mathrm{g}$ 条件 : $\mathrm{r}=-0.884, \mathrm{p}<0.01)$ が認められた. 同様に, $30 \mathrm{~g}$ 条件, $150 \mathrm{~g}$ 条件ともに体重当たりのWmax と血糖值減 少量との間にも有意な負の相関関係 (30 $\mathrm{g}$ 条件: $\mathrm{r}=-0.984$,
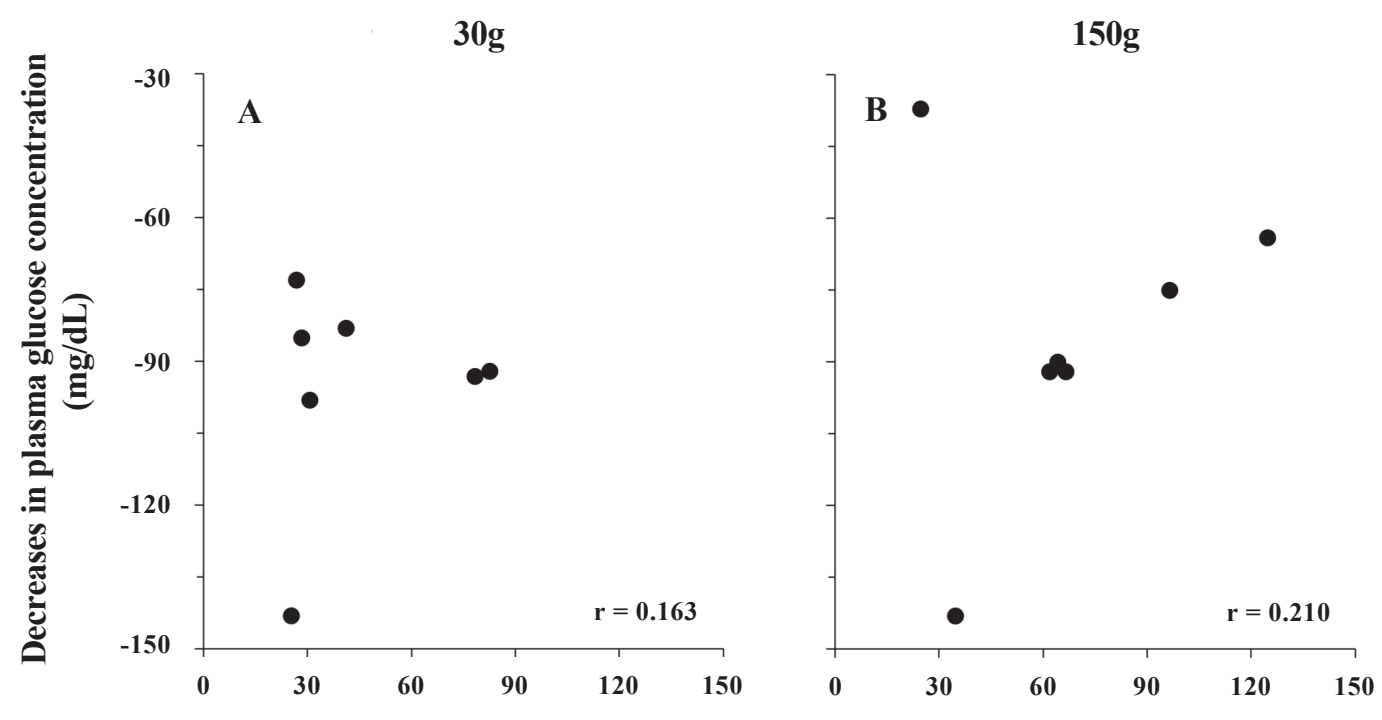

Fig. 5 Relationships between maximum insulin concentrations and changes in plasma glucose concentration from maximum to minimum in $30 \mathrm{~g}(\mathrm{~A})$ and $150 \mathrm{~g}(\mathrm{~B})$ of carbohydrate beverage conditions.

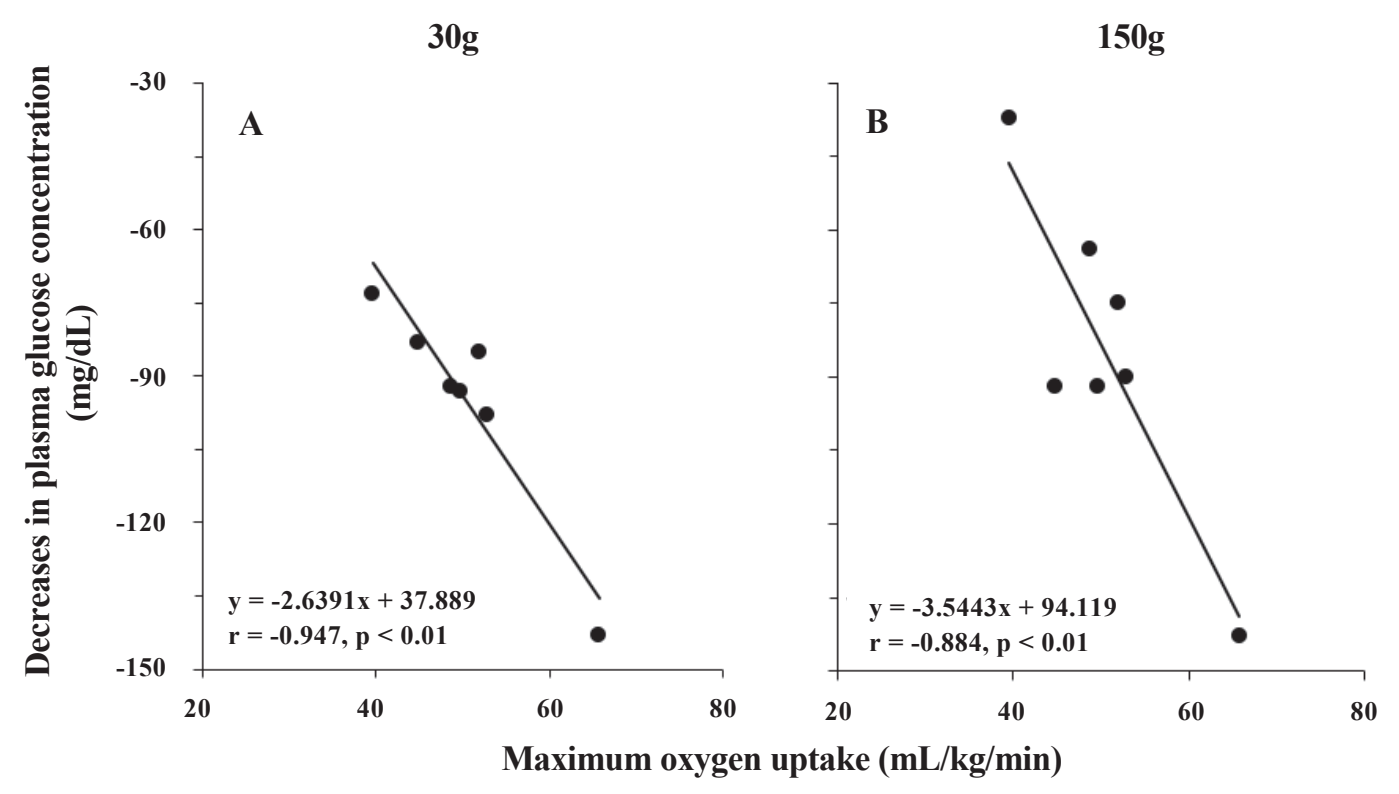

Fig. 6 Relationships between maximum oxygen uptakes $\left(\mathrm{V}_{2} \max \right)$ and changes in plasma glucose concentration from maximum to minimum in $30 \mathrm{~g}$ (A) and $150 \mathrm{~g}$ (B) of carbohydrate beverage conditions. 
$\mathrm{p}<0.01,150 \mathrm{~g}$ 条件 $: \mathrm{r}=-0.881, \mathrm{p}<0.01$ ) が認められた（図 表なし).

体組成と $30 \mathrm{~g}$ 条件および150 g条件における血糖值減 少量との関係 体脂肪率と $30 \mathrm{~g}$ 条件, $150 \mathrm{~g}$ 条件におけ る血糖值減少量との間には有意な相関関係 $(30 \mathrm{~g}$ 条件 : $r=0.128,150 \mathrm{~g}$ 条件 : $r=0.193$ ) は認められなかった（図 表なし). 同様に, 筋肉量と $30 \mathrm{~g}$ 条件, $150 \mathrm{~g}$ 条件におけ る血糖值減少量との間にも有意な相関関係 $(30 \mathrm{~g}$ 条件 : $\mathrm{r}=0.247,150 \mathrm{~g}$ 条件 : $\mathrm{r}=-0.007$ ) は認められなかった（図 表なし).

Og条件における低血糖群と正常血糖群の体重当たりの $\dot{\mathrm{V}} \mathrm{O}_{2} \mathrm{max}$, 血糖值およびインスリン濃度の比較 $0 \mathrm{~g}$ 条 件において，低血糖の基準值を下回った低血糖群と基 準值を下回らなかった正常血糖群の $\dot{\mathrm{V}} \mathrm{O}_{2} \mathrm{max},-35$ 分時 の血糖值および-10分時のインスリン濃度の比較を Fig. 7-A，B，Cに示した。低血糖群では，正常血糖群よりも $\dot{\mathrm{V}} \mathrm{O}_{2} \max$ が低い傾向 $(\mathrm{p}=0.06),-35$ 分時の血糖值および -10 分時のインスリン濃度が高い傾向（血糖值 : $\mathrm{p}=0.16$, インスリン濃度 : $p=0.27 ）$ を示した。

\section{考察}

本研究の結果において, $150 \mathrm{~g}$ 条件の血糖值は, 1 名 の被験者が運動中に低血糖の基準值 $(72 \mathrm{mg} / \mathrm{dL}$ )を下回っ たものの, 平均值は下回らなかった（Fig. 2, Fig. 3-C).

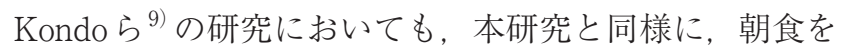
摂取し，運動開始30分前に150 g の糖質飲料を摂取した 場合には，運動中の血糖值が，低血糖の基準值を下回っ
た被験者がいたものの, 平均值では下回らなかったこと が報告されている。よって，本研究における $150 \mathrm{~g}$ 条件 の結果はKondo ら ${ }^{9)}$ の研究の結果と一致したと言える. 一方, 本研究の $30 \mathrm{~g}$ 条件では, 全被験者において運動 中に血糖值が低血糖の基準值を下回り，平均值において も 10〜20分時に低血糖の基準值を下回った（Fig. 2, Fig.

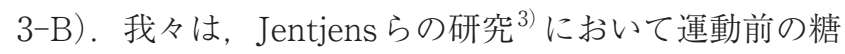
質摂取量の相違が運動中の血糖值変動に影響を及ぼさな かったこと, Kondoらの研究 ${ }^{9)}$ およびKoma and Terasawaの研究 ${ }^{11)}$ において, それぞれ運動直前の $150 \mathrm{~g}$ およ び94.1 gの糖質飲料摂取によって運動中の血糖值の平均 值は低血糖の基準值を下回っていなかったことから，本 研究の $30 \mathrm{~g}$ 条件においても, $150 \mathrm{~g}$ 条件とほほ同様に血 糖值が推移し, 運動中の血糖值は低血糖の基準值を下回 らないと仮説を立てた. しかしながら, この仮説に反し, $500 \mathrm{~mL}$ のペットボトル 1 本分のスポーツドリンクと同 等の糖質量を含む $30 \mathrm{~g}$ の糖質飲料を運動開始30分前に摂 取することで運動中の血糖值は低血糖の基準值を下回っ た。本研究の結果から, 日本人を対象とした朝食摂取 3 時間後における運動開始 30 分前の $30 \mathrm{~g}$ の糖質飲料摂取 は, 運動誘発性低血糖を生じさせることが示唆される。

本研究において $150 \mathrm{~g}$ 条件では運動誘発性低血糖が生 じなかったにも関わらず, $30 \mathrm{~g}$ 条件では生じた要因とし て糖質飲料の糖質濃度の相違が胃排出量に影響を及ほし た可能性が考えられる。 $30 \mathrm{~g}$ および150 g 条件における 糖質飲料の糖質の濃度は $6 \%$ および $30 \%$ であった。 $6 \%$ と $30 \%$ の糖質濃度の飲料を運動開始 30 分前に単回摂取 し, その後の 30 分の安静時および運動中の胃排出量につ いて検討した研究はない.一方, $4.5 \%$ および $17 \%$ の糖質
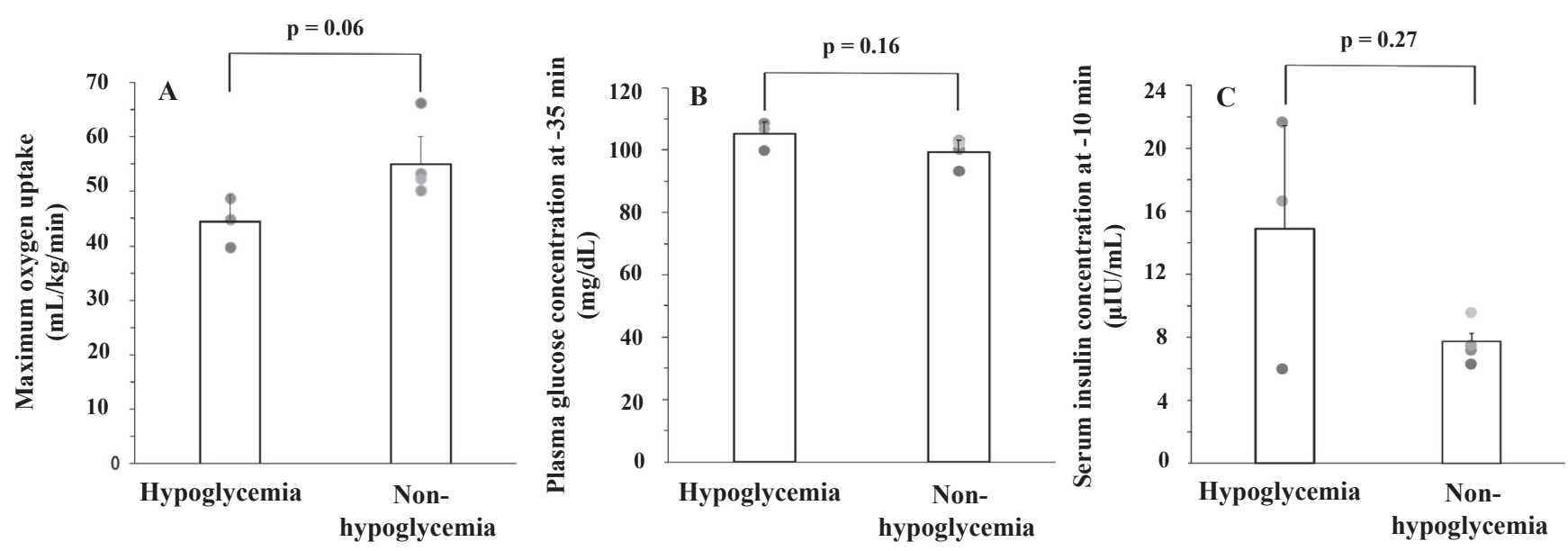

Fig. 7 Comparisons of maximum oxygen uptakes $\left(\dot{\mathrm{VO}}_{2} \max \right)(\mathrm{A})$, plasma glucose concentrations at -35 minutes point (B) and serum insulin concentrations at -10 minutes point between hypoglycemia subjects $(n=3)$ and non- hypoglycemia subjects ( $n=4)$ in $0 \mathrm{~g}$ of carbohydrate beverage conditions. The dots were showing individual subject's values. The bar graphs were mean values in hypoglycemia and non-hypoglycemia subjects. 
濃度の飲料を運動開始時, 運動 20 分, 40 分および 60 分 時に摂取し, $70 \% \dot{\mathrm{V}} \mathrm{O}_{2} \max$ 強度の 80 分の運動後の胃排出 量について検討した研究 ${ }^{17)}$ では, 糖質濃度 $4.5 \%$ では摂 取量の $95 \%$ の容量が胃から排出したのに対し, 糖質濃 度 $17 \%$ では $60 \%$ しか排出せず，40\%が胃に留まったこ とが報告されている，糖質の濃度が高まるほど単位時間 あたりの胃排出量は減少することから, 本研究における 糖質濃度 $30 \%$ の $150 \mathrm{~g}$ 条件では, 飲料が-10分時でも胃 に残っており，運動中も緩徐に胃排出がなされた可能性 が考えられる。 その結果, $150 \mathrm{~g}$ 条件では血糖值が-10 分時から 15 分時まで $30 \mathrm{~g}$ 条件よりも高值傾向で推移し, 20３0分時までは有意に高值で推移したことが示唆さ れる，今後は，糖質飲料にアルギン酸を混合するなど, 胃排出速度の低下を抑えるような工夫 ${ }^{18)}$ をし, 本研究と 同様の検討を行うことで, 本研究の結果が糖質飲料の濃 度の相違によって生じたか否かについて明らかにするこ とができると考えられる。また，運動誘発性低血糖は糖 質飲料濃度が何％以下の場合で生じるのかを明らかにす ることも重要な課題であろう.

本研究に扔いて運動誘発性低血糖の発生要因を明らか にするために, 各被験者の血糖值の最大值から最小值へ の減少量とインスリン濃度の最大值との関係を検討した が, $30 \mathrm{~g}$ 条件, $150 \mathrm{~g}$ 条件ともに, 有意な相関関係は認め られなかった (Fig. 5-B, C). 近藤ら ${ }^{10)}$ は, 朝食摂取後に おける $150 \mathrm{~g}$ の糖質飲料摂取後の $75 \% \mathrm{~V}_{2} \max$ 強度の運 動による血糖值の変化量が- $10 \mathrm{mg} / \mathrm{dL}$ 以内の被験者を変 化なし群, $-10 \mathrm{mg} / \mathrm{dL}$ より大きい被験者を低下群として インスリン濃度の比較を行った。その結果, 両群間で相 違を認めず，インスリン濃度が運動誘発性低血糖に及ぼ す影響は僅少であったことを報告している，よって，本 研究の結果は近藤ら ${ }^{10)}$ の知見を支持する結果であった. また, 近藤ら ${ }^{10)}$ は変化なし群と低下群との間に $\dot{\mathrm{V}} \mathrm{O}_{2} \max$ の相違を認め, 低下群に扔いて $\dot{\mathrm{V}} \mathrm{O}_{2} \max$ が高值であるこ と, さらに, $\dot{\mathrm{V}} \mathrm{O}_{2} \max$ と血糖值変化量との間に有意な負 の相関関係があることを明らかにした，本研究において も, 体重当たりの $\dot{\mathrm{V}} \mathrm{O}_{2} \max$ と血糖值低下量との関係を 確認したところ, $30 \mathrm{~g}$ 条件, $150 \mathrm{~g}$ 条件共に近藤ら ${ }^{10)}$ の 結果と一致する高い負の相関関係を示した（Fig. 6-A， B)。さらに, 体重当たりのWmax と血糖值低下量との 間にも高い負の相関関係が認められた。体重当たりの $\dot{\mathrm{V}} \mathrm{O}_{2} \max$ 抢よびWmaxが高い，すなわち，全身持久力が 高い被験者では, 日常のトレーニングによって5'AMPactivated protein kinase (AMPK) の活性化により骨格 筋の糖輸送体（glucose transporter-4: GLUT4）の発現 量が多く，トランスロケーションするGLUT4が多いこ と ${ }^{19)} に$ 加え，インスリン感受性が高いことから ${ }^{20)}$ ， イ ンスリンの分泌量に依存せずに運動中の骨格筋への糖取 り込みが増大するとされている10)。また，筋量自体が多
ければ，糖取り込み量が多くなり，より血糖值が低下す ることも予想されるが，本研究において，筋量ならびに 体脂肪率の 2 つ体組成に関わる測定項目と $30 \mathrm{~g}$ 条件 および150 g 条件に扔ける血糖值減少量との間には相関 関係は認められなかった。これらのことから，インスリ ン分泌量や筋量ではなく，全身持久力が高い者で朝食摂 取後, 運動 30 分前の糖質飲料摄取により, 運動中の骨 格筋の収縮に伴う骨格筋への糖取り込みにより血糖值低 下量が大きくなり, $30 \mathrm{~g}$ 条件では全被験者において運動 誘発性低血糖が発生した可能性が高いと考えられる。ま た，150g条件では運動誘発性低血糖が確認されたのは 1 名のみであり，上述の胃排出速度の影響で糖質の吸収 速度が遅延した可能性は考えられるものの, 体重当たり の $\dot{\mathrm{V}} \mathrm{O}_{2} \max$ ならびにWmax が高いことが血糖值の減少 に強く影響していることが示唆される.

本研究では $0 \mathrm{~g}$ 条件においても 7 名中 3 名において 10 〜15分時に血糖值が低血糖の基準值を下回った（Fig. 3-A）。この 3 名は低血糖の基準值を下回らなかった被 験者よりも体重当たりの $\dot{\mathrm{V}} \mathrm{O}_{2} \max$ が低い傾向を示した (Fig. 7-A), 先に述べた通り, 体重当たりの $\dot{\mathrm{V}} \mathrm{O}_{2} \max$ はインスリン感受性に影響を及ぼし，体重当たりの $\dot{\mathrm{V}} \mathrm{O}_{2} \max$ が低いほどインスリンによる血糖值低下能が低 い. 低血糖の基準值を下回った 3 名の-35分時の血糖值 の平均值抢よび-10分時のインスリン濃度の平均值は, 低血糖の基準值を下回らなかった被験者のそれらよりも 高值傾向を示した（Fig. 7-B, C)。これらの結果は, 体 重当たりの $\dot{\mathrm{V}} \mathrm{O}_{2} \max$ が低い者では，インスリン感受性が 低いために, 運動開始 3 時間前の朝食摂取によって上昇 した血糖值掞よびインスリン濃度が運動前までに下がり きって扔らず，運動中の骨格筋の収縮に伴う骨格筋への 糖取り込みと同時にインスリンの作用による骨格筋への 糖取り込みが生じ, 低血糖が生じた可能性を示している のかもしれない.

今後検討すべき研究課題として, 糖質飲料の摂取時間 や摂取タイミングに関することが挙げられる，本研究で は, 運動30分前に 2 分以内で $500 \mathrm{~mL}$ の糖質飲料を摂取 した。しかしながら, 運動の現場では500 mLのスポー ツドリンクを 2 分以内に飲みきることは少ないと考えら れる. 本研究と同量の糖質飲料を運動開始前に何回かに 分けて時間をかけて飲んだ場合，本研究と異なる結果が 得られる可能性がある。また, 運動開始 30 分前の糖質 $30 \mathrm{~g}$ の飲料摂取によって運動誘発性低血糖が生じたも のの, 血糖值上昇やインスリン分泌が生じる前の運動開 始直前の摂取では起こらない可能性も考えられる。した がって, 運動誘発性低血糖は運動開始何分前の糖質飲料 摂取から生じるのかについても明らかにする必要がある と考える. 他方, 持久的な運動を行う場合の調整法とし て, 数日前から運動量を減らし, 糖質の多い食事によっ 
て筋グリコーゲンを蓄えるグリコーゲンローディング法 が推奨されている ${ }^{21)}$ 。また, 糖質の多い食事を継続的に 摂取することは胃排出速度の増大を含め, 糖質の消化吸 収に好影響を及ぼすとされる ${ }^{22)}$ 。本研究では実験前日の 夕食および実験当日の朝食のみを統制し, 高糖質食とし た. 今後は, 実験開始数日前から高糖質の食事を摂取し, グリコーゲンローディングを行った場合に本研究と同様 の検討を実施することも必要である，最後に，本研究で は 3 条件 $\times$ 血糖值の測定時点である 8 点から被験者数は 最少の 7 名というサンプルサイズで実験を実施した。し かしながら, 今後は被験者間の個人差を考慮し, さらに サンプルサイズを大きくし，詳細に検討することも必要 であろう。

\section{結 論}

運動開始 3 時間前の朝食摂取後における運動 30 分前の $30 \mathrm{~g}$ の糖質摂取が運動誘発性低血糖を生じさせた.また, 体重当たりの $\dot{\mathrm{V}} \mathrm{O}_{2} \max$ およびWmaxが高いものほど糖質 摂取後の血糖值の最大值から運動開始後の血糖值の最小 值までの減少量が大きかった。以上の結果より, 朝食 摂取後における運動前の現実的な糖質摂取量である $30 \mathrm{~g}$ の糖質を含む飲料を摂取することによって運動誘発性低 血糖が生じ, 特に, 全身持久力が高いもので運動誘発性 低血糖が生じることが示唆された。

利益相反自己申告 : 著者全員が利益相反はない.

\section{著者貢献}

SHおよびTYが，研究をデザインした， SH，IF，NK， MTおよびTYがデー夕収集，分析を担当した。保健師であ るNKは採血を行った。データの解釈はすべての著者が担 当した。草稿はSHおよびTYが担当した，最後にすべての 著者が原稿を批判的にレビューし, 修正し, 投稿を承認した。

\section{引用文献}

1) Coyle EF. Substrate utilization during exercise in active people. Am J Clin Nutr 61: 968S-979S, 1995. doi: 10.1093/ajcn/61.4.968S.

2) Burke LM, Hawley JA, Wong SH, Jeukendrup AE. Carbohydrates for training and competition. J Sports Sci 29: S17-S27, 2011. doi: 10.1080/02640414.2011.585473.

3) Jentjens RL, Cale C, Gutch C, Jeukendrup AE. Effects of pre-exercise ingestion of differing amounts of carbohydrate on subsequent metabolism and cycling performance. Eur J Appl Physiol 88: 444-452, 2003. doi: 10.1007/s00421-002-0727-9.

4) Jentjens RL, Jeukendrup AE. Effects of pre-exercise ingestion of trehalose, galactose and glucose on subsequent metabolism and cycling performance. Eur $J$ Appl Physiol 88: 459-465, 2003. doi: 10.1007/s00421002-0729-7.
5) Achten J, Jeukendrup AE. Effects of pre-exercise ingestion of carbohydrate on glycaemic and insulinaemic responses during subsequent exercise at differing intensities. Eur J Appl Physiol 88: 466-471, 2003. doi: 10.1007/s00421-002-0730-1.

6) Moseley L, Lancaster GI, Jeukendrup AE. Effects of timing of pre-exercise ingestion of carbohydrate on subsequent metabolism and cycling performance. Eur J Appl Physiol 88: 453-458, 2003. doi: 10.1007/s00421002-0728-8.

7) Costill DL, Coyle E, Dalsky G, Evans W, Fink W, Hoopes D. Effects of elevated plasma FFA and insulin on muscle glycogen usage during exercise. $J$ Appl Physiol Respir Environ Exerc Physiol 43: 695-699, 1977. doi: 10.1152/jappl.1977.43.4.695.

8) Ahuja V, Kadowaki T, Evans RW, Kadota A, Okamura T, El Khoudary SR, Fujiyoshi A, Barinas Mitchell EJ, Hisamatsu T, Vishnu A, Miura K, Maegawa H, EI Saed A, Kashiwagi A, Kuller LH, Ueshima H, Sekikawa A. Comparison of HOMA-IR, HOMA- $\beta \%$ and disposition index between US white men and Japanese men in Japan: the ERA JUMP study. Diabetologia 58: 265-271, 2015. doi: 10.1007/s00125-014-3414-6.

9) Kondo S, Tanisawa K, Suzuki K, Terada S, Higuchi M. Preexercise carbohydrate ingestion and transient hypoglycemia: Fasting vs. feeding. Med Sci Sports Exerc 51: 168-173, 2019. doi: 10.1249/MSS.0000000000001773.

10）近藤早希, 谷澤薰平, 鈴木克彦, 寺田 新, 樋口 満 : 運動誘 発性低血糖時の血糖変化量の再評価: 安静時との比較, 日本スポーツ栄養研究誌, 12: 77-85, 2019.

11) Koma R, Terasawa N. Pre-exercise glucose ingestion may improve endurance capacity in east asian student athletes with lower blood glucose response. J Nutr Sci Vitaminol (Tokyo) 66: 150-157, 2020. doi: 10.3177/ jnsv.66.150.

12）公益財団法人日本体育協会. スポーツ活動中の熱中症予 防ガイドブック, 16, 2006.

13) Jeukendrup A. A step towards personalized sports nutrition: carbohydrate intake during exercise. Sports Med 44: S25-33, 2014. doi: 10.1007/s40279-014-0148-z.

14）水本 篤, 竹内 理: 効果量と検定力分析入門 - 統計的検 定を正しく使うために一, 2010年度部会報告論集「より 良い外国語教育のための方法」, 47-73, 2011.

15）佐藤未来, 山口太一, 東郷将成, 保科圭汰, 八田早那子, 藤 江衣織, 瀧澤一騎, 神林 勲: 月経周期が漸増多段階運動 負荷試験に伴う脂質酸化量および全身持久力に与える 影響, 北海道体育学研究, 54: 73-79, 2019.

16) van Loon LJ, Greenhaff PL, Constantin-Teodosiu D, Saris WH, Wagenmakers AJ. The effects of increasing exercise intensity on muscle fuel utilisation in humans. J Physiol 536: 295-304, 2001. doi: 10.1111/j.14697793.2001.00295.x.

17) Rehrer NJ, Wagenmakers AJ, Beckers EJ, Halliday D, Leiper JB, Brouns F, Maughan RJ, Westerterp K, Saris WH. Gastric emptying, absorption, and carbohydrate oxidation during prolonged exercise. J Appl Physiol 72: 468-475, 1992. doi: 10.1152/jappl.1992.72.2.468. 
18) Sutehall S, Muniz-Pardos B, Bosch AN, Di Gianfrancesco A, Pitsiladis YP. Sports drinks on the edge of a new era. Curr Sports Med Rep 17: 112-116, 2018. doi: 10.1249/JSR.0000000000000475.

19) Kristiansen S, Gade J, Wojtaszewski JF, Kiens B, Richter EA. Glucose uptake is increased in trained vs. untrained muscle during heavy exercise. J Appl Physiol 89: 1151-1158, 2000. doi: 10.1152/jappl.2000.89.3.1151.

20) Ebeling P, Bourey R, Koranyi L, Tuominen JA, Groop LC, Henriksson J, Mueckler M, Sovijarvi A, Koivisto VA. Mechanism of enhanced insulin sensitivity in athletes. Increased blood flow, muscle glucose transport protein (GLUT- 4) concentration, and glycogen synthase activity. J Clin Invest 92: 1623-1631, 1993. doi: 10.1172/JCI116747.

21) Casazza GA, Tovar AP, Richardson CE, Cortez AN, Davis BA. Energy availability, macronutrient intake, and nutritional supplementation for improving exercise performance in endurance athletes. Curr Sports Med Rep 17: 215-223, 2018. doi: 10.1249/ JSR.0000000000000494.

22) Jeukendrup AE. Training the gut for athletes. Sports Med 47: 101-110, 2017. doi: 10.1007/s40279-017-0690-6. 